\title{
Effect of Genital Tuberculosis on Ovarian Reserve
}

\author{
Padma Rekha Jirge \\ Sushrut Assisted Conception Clinic and Shreyas Hospital, Kolhapur, Maharashtra, India
}

DOI: https://doi.org/10.17925/USE.2020.16.2.104

F emale genital tuberculosis (FGTB) is a known cause of infertility due to tubal damage and, less often, endometrial damage. However, its impact on ovarian damage is poorly understood and has only come to focus in recent years. Availability of robust ovarian reserve markers, such as anti-Mullerian hormone and antral follicle count, have contributed to an improved understanding of ovarian reserve in FGTB. Pre-treatment assessment of ovarian reserve and ovarian response during in vitro fertilization has shown that FGTB adversely affects the ovarian reserve. Interestingly, there is some evidence that treatment with antitubercular therapy may lead to both qualitative and quantitative improvement in ovarian reserve. As it appears to be a reversible cause of poor ovarian reserve, timely diagnosis and treatment may lead to an improvement in fertility outcome in women affected with FGTB.

\section{Keywords}

Female genital tuberculosis, latent genital tuberculosis, infertility, ovarian reserve, anti-Mullerian hormone

Disclosures: Padma Rekha Jirge has no financial or non-financial relationships or activities to declare in relation to this article.

Review Process: Double-blind peer review.

Compliance with ethics: This article involves a review of the literature and did not involve any studies with human or animal subjects performed by the author.

Authorship: The named author meets the International Committee of Medical Journal Editors (ICMJE) criteria for authorship of this manuscript, takes responsibility for the integrity of the work as a whole, and has given final approval for the version to be published.

Access: This article is freely accessible at touchENDOCRINOLOGY.com (c) Touch Medical Media 2020

Submitted: July 18, 2020

Accepted: November 2, 2020

Published Online: December 16, 2020

Citation: US Endocrinology. 2020;16(2):104-8

Corresponding Author: Padma Rekha Jirge, Sushrut Assisted Conception Clinic \& Shreyas Hospital, $2013 \mathrm{E}, 6^{\text {th }}$ Lane, Rajarampuri, Kolhapur -416008

Maharashtra, India. E: rekha.jirge@gmail.com

Support: No funding was received in

the publication of this article.
Tuberculosis (TB), caused by Mycobacterium tuberculosis, continues to be a major cause of ill health and the most common cause of death attributed to a single microbial agent, across the world. ${ }^{1}$ However, an important limitation to the efforts of World Health Organization (WHO) for ending TB is the presence of a large reservoir of latent TB infection. ${ }^{2}$ In addition to the annual incidence of 8-10 million of pulmonary and extrapulmonary TB cases, nearly one-third of the worlds's population harbors latent TB infection. ${ }^{3}$ Though it is not communicable in itself, latent TB infection has a high conversion rate of $5-10 \%$ to active disease. ${ }^{2,3}$ This occurs usually within the first 5 years of initial infection, which is further accelerated in immunocompromised individuals. ${ }^{2.3}$ Importantly, it elicits an immune response from the host tissue to Mycobacterium tuberculosis antigens, with consequent damage to host tissue. ${ }^{3-6}$

Genital TB (GTB) accounts for 9-15\% of extrapulmonary TB. ${ }^{7-9}$ It is the underlying cause for infertility in 5-20\% of women who are infertile. ${ }^{10-14}$ Further, infertility may be the sole symptom of female genital tuberculosis (FGTB) due to its paucibacillary nature. ${ }^{14-17}$ The implications to fertility as a result of tubal or endometrial damage are well-documented. ${ }^{18-22}$ Tuberculous involvement of the cervix, vagina, or vulva is rare and accounts for $5 \%$ of FGTB; ${ }^{23-27}$ the association of TB in these organs with infertility remains unexplored. Ovarian involvement is found in up to $30 \%$ of women with FGTB; ${ }^{: 11,13,28}$ however, its impact on female reproductive health is only beginning to be explored. ${ }^{29-31}$

A comprehensive understanding of the impact of FGTB on reproductive health is necessary due to an increasing incidence of $\mathrm{TB}$, even in low-burden countries, due to transnational and transcontinental migration of people from high-burden countries, and an accelerated conversion of latent TB infection to active TB in immunocompromised individuals. ${ }^{12,20,22,32}$ This narrative review critically looks at the role of FGTB on ovarian reserve and its implications to reproductive health of women.

An electronic literature search was performed in Medline (1966-2020) using search terms "female genital tuberculosis", "latent genital tuberculosis", and "ovarian reserve". A total of 6,791 articles were retrieved. All studies that included 10 or more patients evaluating ovarian reserve in women who are infertile with FGTB, were included. Further searches were made for individual diagnostic modalities for FGTB and ovarian reserve tests using their titles as key words. Appropriate cross-references were manually searched. The search strategy is shown in Figure 1.

\section{Genital tuberculosis and ovarian function}

Ovarian damage consequent to a tuberculous ovarian abscess or tubo-ovarian mass is seen in up to $25-30 \%$ of women with suspected or diagnosed FGTB on ultrasound and/or laparoscopic assessment. 19,23,33 Decline in ovarian reserve in such women, due to loss of part or all of the ovary, is evident. However, more subtle damage to ovarian function and ovarian reserve cannot be ruled 


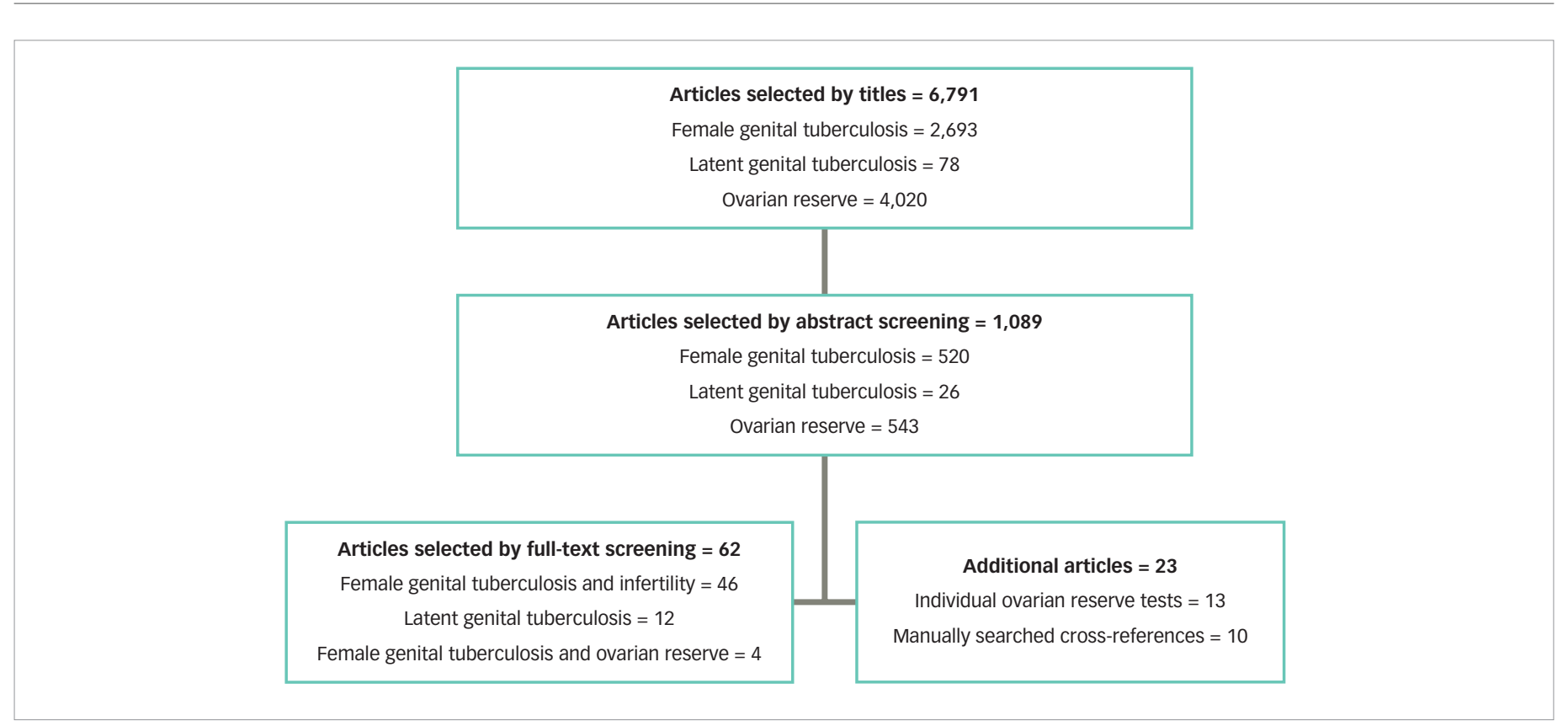

out, even when the disease remains latent and entirely undetected. ${ }^{30,34}$ The paucibacillary nature of FGTB, its latency, the challenges involved in its diagnosis, and the diminished ovarian reserve are important limitations in understanding the association between FGTB and ovarian reserve.

\section{Diagnosis of ovarian involvement in female genital tuberculosis}

Radiological investigations such as transvaginal ultrasonography, hysterosalpingography, and magnetic resonance imaging (MRI); and endoscopic assessment by laparoscopy and hysteroscopy are useful modalities for pelvic evaluation and for clinical diagnosis of FGTB. ${ }^{19-21,33,35-40}$ Ultrasound findings of edematous ovaries, complex tubo-ovarian masses, calcification spots in ovaries, or hydrosalpinges should raise the possibility of FGTB. ${ }^{33} \mathrm{MRI}$ is helpful in the evaluation of a complex adnexal masses when the ultrasound findings remain inconclusive. ${ }^{37}$ Further, both these modalities provide a comprehensive, non-invasive assessment of the pelvis and abdomen. However, the paucibacillary nature of FGTB makes bacteriological diagnosis through conventional methods challenging. 14,41-43 Smear and microscopy, histopathology, and bacterial culture all require a high bacterial load for the diagnosis of TB. In addition, bacterial plasticity and mechanisms leading to latency result in loss of culturability.44,45

Difficulties in obtaining an adequate tissue biopsy from various affected areas without causing further damage to the female genital tract makes endometrial tissue the most widely used source for bacteriological diagnosis of FGTB. ${ }^{38,41}$ Concerns regarding invasive nature of ovarian biopsy and risk of adhesion formation are important reasons against performing an ovarian biospsy. ${ }^{46,47}$ Possible damage to ovarian reserve and missing an area of localized infection are additional reasons for not performing an ovarian biopsy to establish a bacteriological or molecular diagnosis of ovarian TB. A single study evaluating the role of endo-ovarian biopsy in diagnosing FGTB found it to be an effective tool for diagnosis, identifying mycobacterial DNA in one-third of the biopsies; however, the study did not address the safety issues of the procedure. ${ }^{48}$
Molecular diagnostic tests, in particular, DNA polymerase chain reaction (PCR), are increasingly used for the diagnosis of extrapulmonary TB, including FGTB. ${ }^{14,20,41,49-51}$ Molecular tests have high sensitivity and specificity in diagnosing paucibacillary conditions as they require very few copies of bacterial DNA. Multiplex DNA PCR, using gene probes specific to bacterial genotypes most prevalent in different geographic areas, are reported to be of high diagnostic value. . $1,51-54^{-54}$

When FGTB is clinically suspected in an infertile woman with a tubo-ovarian mass in the absence of bacteriological or molecular confirmation, other causes of pelvic infection, endometriosis, and even ovarian malignancy should be considered and excluded. ${ }^{55-60}$ Conversely, women with protracted, unexplained infertility may benefit from an active evaluation for FGTB.

\section{Ovarian reserve in female genital tuberculosis}

The previous section highlights the difficulties in establishing a direct bacteriological diagnosis of ovarian TB. Hence, ovarian reserve assessment has been used as a surrogate marker to identify ovarian damage in those with FGTB. ${ }^{29,30,61}$ Ovarian reserve is the quantitative measure of primordial follicular pool. It shows a progressive decline with age and is accompanied by a qualitative decline in those older than 38 years of age. ${ }^{.2-64}$ Ovarian reserve is assessed in two different ways. Historically, response to conventional protocols of ovarian stimulation in the first cycle of IVF has been considered as the "gold standard." ${ }^{65-67}$ Dose of gonadotropins required, duration of ovarian stimulation, and oocyte yield constitute the ovarian response and offer a post-treatment understanding of ovarian reserve. ${ }^{64}$ However, pre-treatment assessment of ovarian reserve to predict ovarian response to in vitro fertilization (IVF) has become a routine practice in recent years. This includes endocrine markers of basal follicle-stimulating hormone (FSH), inhibin-B, anti-Mullerian hormone $(\mathrm{AMH})$, and ultrasound markers of antral follicle count (AFC) and ovarian volume. ${ }^{65-68} \mathrm{AMH}$ is the most widely used marker to predict ovarian response in IVF, due to its minimal intracycle and intercycle variations, and its high sensitivity and specificity, similar to that of AFC. ${ }^{69-73}$ In addition, $\mathrm{AMH}$ is the earliest marker to unmask declining 
Table 1: Studies evaluating ovarian response in vitro fertilization and ovarian reserve in women who are infertile with genital tuberculosis

\begin{tabular}{|c|c|c|c|}
\hline Study & Patient population & Parameters evaluated & Findings \\
\hline Gurgan et al. $1996^{61}$ & $\begin{array}{l}\text { Comparative study: } \\
24 \text { women with tubercular tubal factor versus } 366 \\
\text { with non-tubercular tubal factor }\end{array}$ & $\begin{array}{l}\text { - Pre-IVF basal FSH } \\
\text { - Ovarian response during IVF } \\
\text { - Clinical pregnancy rate } \\
\text { - Miscarriage rate }\end{array}$ & $\begin{array}{l}\text { Women with GTB: } \\
\text { - Higher basal FSH } \\
\text { - In IVF: } \\
\text { increased gonadotropin requirement } \\
\text { reduced peak estradiol } \\
\text { reduced oocytes, embryos } \\
\text { low clinical pregnancy rate } \\
\text { increased miscarriage rate }\end{array}$ \\
\hline Dam et al. $2006^{34}$ & $\begin{array}{l}\text { Latent GTB and RIF in IVF: } \\
40 \text { women with RIF before and after ATT }\end{array}$ & $\begin{array}{l}\text { IVF parameters-pre- and post ATT: } \\
\text { - Ovarian response } \\
\text { - Clinical PR }\end{array}$ & $\begin{array}{l}\text { Post treatment with ATT: } \\
\text { reduced gonadotropin requirement } \\
\text { increased oocyte yield } \\
\text { higher grade I embryos } \\
\text { increased clinical PR }\end{array}$ \\
\hline Malhotra et al. $2012^{29}$ & $\begin{array}{l}\text { Cross-sectional study: } \\
104 \text { infertile women with GTB versus } 104 \text { healthy } \\
\text { fertile controls }\end{array}$ & $\begin{array}{l}\text { - Basal FSH, LH, inhibin B } \\
\text { - Ovarian volume, AFC } \\
\text { - Ovarian stromal blood flow on } \\
\text { doppler }\end{array}$ & $\begin{array}{l}\text { In women with GTB: } \\
\text { elevated basal FSH, LH } \\
\text { low inhibin-B } \\
\text { low ovarian volume and AFC } \\
\text { reduced PSV and PI }\end{array}$ \\
\hline Sharma et al. $2016^{31}$ & $\begin{array}{l}\text { Longitudinal Study: } \\
50 \text { women with GTB } \\
\text { - Ovarian reserve markers pre- and post ATT }\end{array}$ & $\begin{array}{l}\text { - FSH, AMH, AFC, ovarian volume } \\
\text { - Ovarian Doppler-PSV, PI, and RI }\end{array}$ & $\begin{array}{l}\text { Post ATT: } \\
\text { improved AMH and AFC } \\
\text { Improved Doppler parameters }\end{array}$ \\
\hline Jirge et al. $2018^{30}$ & $\begin{array}{l}\text { Comparative Study: } \\
395 \text { infertile women with latent GTB versus } 383 \\
\text { infertile women with unexplained infertility }\end{array}$ & $\begin{array}{l}\text { - FSH, AMH, AFC } \\
\text { - Pregnancy outcome post ATT }\end{array}$ & $\begin{array}{l}\text { In women with latent GTB: } \\
\text { Iow AMH and AFC } \\
\text { POst ATT: } \\
\text { In ovulation induction—-higher PR } \\
\text { In IVF--better embryo grades despite less oocytes } \\
\text { and higher PR }\end{array}$ \\
\hline
\end{tabular}

AFC = antral follicle count; $A M H=$ anti-Mullerian hormone; $A T T=$ antitubercular treatment; GTB = genital tuberculosis; FSH = follicle stimulating hormone; IVF = in vitro fertilization; $L H=$ leutinizing hormone; $P I=$ pulsatality index; $P R=$ pregnancy rate; $P S V=$ peak systolic velocity; $R I=$ resistance index; $R I F=$ recurrent implantation failure; $T B=$ tuberculosis.

ovarian reserve even in young women, compared with any other marker of ovarian reserve. ${ }^{74,75} \mathrm{As} \mathrm{AMH}$ and AFC show an age-related decline, the diagnosis of poor ovarian reserve would be based on age-specific abnormal values, where population-based nomograms exist.76,77 However, an $\mathrm{AMH}$ of $<1.2 \mathrm{ng} / \mathrm{mL}$ or $\mathrm{AFC}<5$ in anyone below 40 years of age would be considered as indicators of poor ovarian reserve. ${ }^{78}$

Suboptimal outcomes in women with FGTB undergoing IVF have been reported since the early years of IVF. Women with FGTB-associated tubal factor infertility have been seen to have lower pregnancy rates compared to those with non-tuberculous tubal infertility. ${ }^{61,79}$ Evidence from different patient populations has consistently revealed suboptimal ovarian response in women with FGTB. They exhibit an increased requirement of gonadotropin and duration of ovarian stimulation, and yield a lower number of oocytes and/or embryos during IVF.30,34,61 A study comparing ovarian response in women with latent GTB before and after antitubercular therapy has shown an improvement in ovarian response, including oocyte yield and embryo quality post-treatment. ${ }^{31}$

With the advent of endocrine markers for assessing ovarian reserve, attempts have been made to evaluate the effect of FGTB on ovarian reserve prior to IVF. Basal FSH, the oldest marker utilized to predict poor ovarian reserve, was found to be higher in women with FGTB compared to those with other causes of infertility during pre-IVF assessment.29,61
Inhibin-B levels and AFC were lower in those with FGTB compared to healthy controls. ${ }^{29}$ Importantly, evidence from a single large study shows that $\mathrm{AMH}$ and $\mathrm{AFC}$ are lower in women who are infertile with latent GTB without any laparoscopic evidence of TB compared to those with unexplained infertility. ${ }^{30}$ The above evidence, albeit limited, does indicate an adverse impact of FGTB on ovarian reserve, and is summarized in Table 1.29:31,34,61

\section{Mechanism of ovarian injury in female genital tuberculosis}

The mechanism/s of ovarian damage in FGTB remain poorly understood. A lipid, nitric oxide, and steroid-hormone-rich environment in the ovary may encourage both infection and its latency. Conditions such as endometriosis leading to altered local immunity may further enhance the occurrence of FGTB. ${ }^{59}$ In those with ovarian abscess or clinically diagnosed oophoritis, inflammatory and vascular damage, followed by fibrosis similar to that seen in pulmonary TB, can be anticipated. Ovarian Doppler assessment has shown high resistance flow in the ovarian arteries in women with FGTB and poor ovarian reserve. ${ }^{29,31}$ However, when ovarian involvement is not diagnosed clinically, and in latent TB, there may be a combination of immunological and endocrine response resulting in chronic inflammatory damage. ${ }^{6,80-82}$ Alternatively, the damage may preferentially be to the growing pool of follicles, as observed during gonadotoxic chemotherapy. ${ }^{83}$ This, in part, may explain the rise in $\mathrm{AMH}$ following antitubercular therapy 
indicating restoration and recruitment from the unaffected primordial follicular pool.

\section{Treatment of female genital tuberculosis}

Treatment of FGTB involves standard antitubercular therapy for 6 months. This includes oral administration of four drugs-isoniazid, rifampicin, ethambutol, and pyrazinamide-for the initial 2 months of the intensive phase, followed by the first three drugs (isoniazid, rifampicin, ethambutol) for another 4 months of the continuation phase. ${ }^{14}$ Current evidence suggests improved pregnancy outcomes following treatment of FGTB, both with simple forms of treatment and IVF. $30,34,84$

\section{Fertility outcomes following antitubercular therapy}

The evaluation of endocrine and Doppler parameters in women with FGTB, before and after antitubercular therapy, has shown an improvement in $\mathrm{AMH}$, AFC, and other Doppler parameters. ${ }^{31}$ It is known that the pregnancy rate in IVF is influenced by the number of oocytes. ${ }^{85}$ Observation from IVF in women previously treated for FGTB does not conform to this norm. On the contrary, they have higher number of good-quality embryos and a higher pregnancy rate compared to those with unexplained infertility, despite lower AMH and oocyte yield. ${ }^{30}$ Similarly, in women with recurrent implantation failure diagnosed and treated for latent TB infection, improved ovarian response and embryo quality is noted in comparison to their failed IVF cycles. ${ }^{34}$ This does suggest a qualitative improvement in the ovarian environment following antitubercular therapy. Also, these findings support the hypothesis that the adverse impact on ovarian reserve, due to FGTB, may be halted or even reversed with antitubercular therapy. This is very important in the context of poor ovarian reserve, encountered in about $20 \%$ of women who are infertile, and its negative correlation with fertility. ${ }^{64,86}$ Further, women with poor ovarian reserve are likely to experience early menopause. ${ }^{87}$ These concerns underline the importance of active evaluation of women with infertility due to FGTB in high-burden countries, and selective screening and investigation in low-burden countries. ${ }^{22}$
A high index of suspicion, molecular diagnostic tests on endometrial tissue, and assessment of ovarian reserve markers are necessary to diagnose both the infection and its adverse impact on ovarian function. There is a need for clarity on the diagnostic tests with high accuracy, that are effective in both latent and active conditions. Serological investigations do not have any place in the diagnosis of genital infection in high-burden countries. ${ }^{2}$ Additionally, awareness among clinicians regarding the need for evaluation of ovarian reserve in women with suspected or confirmed FGTB is important. It would be interesting to evaluate any difference in the magnitude of reduction in ovarian reserve amongst those with clinically diagnosed and latent FGTB. A composite reference standard of infertility and the presence of one additional clinical, radiological, endoscopic, or endocrine criterium may be used to compare the diagnostic efficacy of bacteriological or molecular tests. Judicious application of tests is of paramount importance in view of the limited volume of samples available for any assessment. Very young women may pose a challenge as $\mathrm{AMH}$ reaches its physiological peak at 25 years of age. ${ }^{88}$ Prevailing evidence also emphasizes the need for a strategy to evaluate all women with refractory infertility in high-burden countries and selectively in low-burden countries for FGTB.

\section{Conclusions}

Current evidence highlights an adverse impact of FGTB, including latent GTB, on ovarian reserve. Though the actual incidence of ovarian involvement in FGTB may not be known at present, its negative effect on ovarian reserve is seen in both pre-treatment assessment and following ovarian stimulation during IVF. With a lack of consensus regarding timing and type of investigations for FGTB, it is likely being underdiagnosed. Treatment with antitubercular therapy improves the fertility outcome in women with GTB and may also lead to an improvement in ovarian reserve. Development of a policy of selective or universal testing for FGTB in women who are infertile in low- and high-burden countries, respectively, is necessary to reduce the growing burden of poor ovarian reserve in women who are infertile. $\square$
1. World Health Organization, Global tuberculosis report 2019 2019. Available at: https://apps.who.int/iris/bitstream/hand le/10665/329368/9789241565714-eng.pdf?ua=1 (accessed November 10, 2020).

2. World Health Organization, Latent tuberculosis infection: updated and consolidated guidelines for programmatic management, 2018. Available at: https://apps.who.int/iris/bitstream/han dle/10665/260233/9789241550239-eng.pdf?sequence $=1$ (accessed November 10, 2020).

3. Getahun $\mathrm{H}$, Matteelli A, Chaisson RE, Raviglione M. Latent Mycobacterium tuberculosis infection. N Engl J Med. 2015;372:2127-35

4. Wigginton JE, Kirschner D. A model to predict cell-mediated immune regulatory mechanisms during human infection with Mycobacterium tuberculosis. J Immunol. 2001;166:1951-67.

5. Lin PL, Flynn JL. Understanding latent tuberculosis: a moving target. J Immunol. 2010;185:15-22.

6. Mustafa T, Mogga SJ, Mfinanga SG, et al. Immunohistochemical analysis of cytokines and apoptosis in tuberculous lymphadenitis. Immunology. 2006;117:454-62.

7. Sandgren A, Hollo V, Van der Werf M. Extrapulmonary tuberculosis in the European union and European economic area, 2002 to 2011. Eurosurveillance. 2013;18:20431.

8. Gatongi DK, Gitau G, Kay V, et al. Female genital tuberculosis. Obstet Gynaecol. 2005;7:75-9.

9. Golden MP, Vikram HR. Extrapulmonary tuberculosis: an overview. Am Fam Physician. 2005;72:1761-8.

10. Chowdhury NN. Overview of tuberculosis of the female genital tract. I Indian Med Assoc. 1996;94:345-61.

11. Gupta N, Sharma JB, Mittal S, et al. Genital tuberculosis in Indian infertility patients. Int J Gynaecol Obstet. 2007;97:135-8.

12. Türkmen IC, Başsüllü N, Comunoğlu C, et al. Female genital system tuberculosis: a retrospective clinicopathological study of 1,548 cases in Turkish women. Arch Gynecol Obstet. 2012;286:379-84.

13. Sharma JB. Current diagnosis and management of female genita tuberculosis. J Obstet Gynaecol India. 2015;65:362-71.
14. Ministry of Health and Family Welfare, Index-TB guidelines: guidelines on extra-pulmonary tuberculosis for India. Available at: tbcindia.nic.in/showfile. .php?lid=3245 (accessed November 10, 2020).

15. Ghosh K, Ghosh K, Chowdhury JR. Tuberculosis and female reproductive health. J Postgrad Med. 2011;57:307-13.

16. Prasad S, Singhal M, Negi SS, et al. Targeted detection of $65 \mathrm{kDa}$ heat shock protein gene in endometrial biopsies for reliable diagnosis of genital tuberculosis. Eur J Obstet Gynecol Reprod Biol. 2012;160:215-8.

17. Legro RS, Hurtado RM, Kilcoyne A, Roberts DJ. Case records of the massachusetts general hospital. Case 28-2016: a 31-year-old woman with infertility N Eng/ I Med. 2016:375:1069-77.

18. Sharma JB, Roy KK, Pushparaj M, et al. Genital tuberculosis: an important cause of Asherman's syndrome in India. Arch Gynecol Obstet. 2008;27:37-41

19. Parikh FR, Nadkarni SG, Kamat SA, et al. Genital tuberculosis--a major pelvic factor causing infertility in Indian women. Fertil Steril. 1997;67:497-500.

20. Nezar M, Goda H, El-Negery M, El-Saied M, Wahab AA, Badawy AM. Genital tract tuberculosis among infertile women: an old problem revisited. Arch Gynecol Obstet. 2009:280:787-91

21. Sharma JB, Sneha J, Singh UB, et al. Comparative study of laparoscopic abdominopelvic and fallopian tube findings before and after antitubercular therapy in female genital tuberculosis with infertility. J Minim Invasive Gynecol. 2016;23:215-22.

22. Tal R, Lawal T, Granger E, et al. Genital TB screening at an academic fertility center in the US. Am J Obstet Gynecol. 2020;223:737.e1-737.e10

23. Sharma JB, Sharma E, Sharma S, Dharmendra S. Female genital tuberculosis: revisited. Indian J Med Res. 2018;148:S71-83.

24. Buppasiri P, Temtanakitpaisan T, Somboonporn W. Tuberculosis at vulva and vagina. J Med Assoc Thai. 2010;93:613-5.

25. Neonakis IK, Spandidos DA, Petinaki E. Female genital tuberculosis: a review. Scand I Infect Dis. 2011;43:564-72.

26. Mandato VD, Sacchetti F, Costagliola L, La Sala GB. Primary tuberculosis of the uterine cervix: keep it in mind. I Low Genit
Tract Dis. 2014;18:E29-33.

27. Bharani V, Gupta N, Suri V, Rajwanshi A. Tuberculosis in Pap samples with emphasis on LBC: Caught only when thought. Diagn Cytopathol. 2018:46:425-8.

28. Efared B, Sidibé IS, Erregad F, et al. Female genital tuberculosis: a clinicopathological report of 13 cases. I Surg Case Rep. 2019;2019:riz083

29. Malhotra N, Sharma V, Bahadur A, et al. The effect of tuberculosis on ovarian reserve among women undergoing IVF in India. Int J Gynaecol Obstet. 2012;117:40-4.

30. Jirge PR, Chougule SM, Keni A, et al. Latent genital tuberculosis adversely affects the ovarian reserve in infertile women. Hum Reprod. 2018:33:1262-9.

31. Sharma JB, Sneha J, Singh UB, et al. Effect of antitubercular treatment on ovarian function in female genital tuberculosis with infertility. J Hum Reprod Sci. 2016;9:145-50.

32. Al Abri S, Kasaeva T, Migliori GB, et al. Tools to implement the World Health Organization End TB Strategy: addressing common challenges in high and low endemic countries. Int I Infect Dis. 2020;92S:S60-8.

33. Shah HU, Sannananja B, Baheti AD, et al. Hysterosalpingography and ultrasonography findings of female genital tuberculosis. Diagn Interv Radiol. 2015;21:10-5.

34. Dam P, Shirazee HH, Goswami SK, et al. Role of latent genital tuberculosis in repeated IVF failure in the Indian clinical setting Gynecol Obstet Invest. 2006;61:223-7.

35. Chavhan GB, Hira P, Rathod K, et al. Female genital tuberculosis: hysterosalpingographic appearances. Br J Radiol. 2004;77:164-9.

36. Madjid TH, Ardhi I, Permadi W, et al. Correlation of clinical features, laboratory finding, and pelvic ultrasonography of pulmonary tuberculosis women with infertility. Int J Gen Med. 2019;12:485-9.

37. Sharma JB, Karmakar D, Hari S, et al. Magnetic resonance imaging findings among women with tubercular tubo-ovarian masses. Int I Gynaecol Obstet. 2011;113:76-80.

38. Malhotra N, Singh UB, lyer V, et al. Role of laparoscopy in the diagnosis of genital TB in infertile females in the era of molecular tests. J Minim Invasive Gynecol. 2020;27:1538-44. 
39. Sharma JB, Roy KK, Pushparaj M, Kumar S. Hysteroscopic findings in women with primary and secondary infertility due to genital tuberculosis. Int J Gynaecol Obstet. 2009;104:49-52.

40. Scrimin F, Limone A, Wiesenfeld U, Guaschino S. Tubercular endometritis visualized as endometrial micropolyps during hysteroscopic procedure Arch Gynecol Obstet. 2010;281:1079-80.

41. Bhanu NV, Singh UB, Chakraborty M, et al. Improved diagnostic value of PCR in the diagnosis of female genital tuberculosis leading to infertility. J Med Microbiol. 2005;54:927-31.

42. Jindal UN. An algorithmic approach to female genital tuberculosis causing infertility. Int J Tuberc Lung Dis. 2006;10:1045-50.

43. Agrawal M, Roy P, Bhatia V, et al. Role of microbiological tests in diagnosis of genital tuberculosis of women with infertility: a view. Indian J Tuberc. 2019:66:234-9.

44. Gample SP, Agrawal S, Sarkar D. Evidence of nitrite acting as a stable and robust inducer of non-cultivability in Mycobacterium tuberculosis with physiological relevance. Sci Rep. 2019;9:9261.

45. Salina EG, Mollenkopf HJ, Kaufmann SHE, Kaprelyants AS. M. tuberculosis gene expression during transition to the 'non-culturable' state. Acta Naturae. 2009;1:73-7.

46. Sharara Fl, Scott RT. Assessment of ovarian reserve. Is there still a role for ovarian biopsy? First do no harm! Hum Reprod. 2004;19:470-1.

47. Kwok R, Johnson NP. Ovarian biopsy has no role as a routine diagnostic test of ovarian reserve: a systematic review. Reprod Biomed Online. 2012;24:492-5.

48. Bhanothu V, Theophilus JP, Rozati R. Use of endo-ovarian tissue biopsy and pelvic aspirated fluid for the diagnosis of female genital tuberculosis by conventional versus molecular methods. PLOS One. 2014;9:e98005.

49. Thangappah RB, Paramasivan CN, Narayanan S. Evaluating PCR, culture \& histopathology in the diagnosis of female genital tuberculosis. Indian J Med Res. 2011;134:40-6.

50. Goel G, Khatuja R, Radhakrishnan G, et al. Role of newer methods of diagnosing genital tuberculosis in infertile women. Indian J Pathol Microbiol. 2013;56:155-7.

51. Sankar MM, Kumar P, Munawwar A, et al. Usefulness of multiplex PCR in the diagnosis of genital tuberculosis in females with infertility. Eur I Clin Microbiol Infect Dis. 2013:32:399-405.

52. Bhanothu V, Theophilus JP, Reddy PK, Rozati R. Occurrence of female genital tuberculosis among infertile women: a study from a tertiary maternal health care research centre in South India. Eur J Clin Microbiol Infect Dis. 2014;33:1937-49.

53. Sharma K, Appannanavar SB, Modi M, et al. Role of multiplex polymerase chain reaction using IS6110 and Protein $b$ for the diagnosis of extra-pulmonary tuberculosis: North India. Indian J Pathol Microbiol. 2015:58:27-30.

54. Sinha P Gupta A, Prakash P et al. Differentiation of Mycobacterium tuberculosis complex from non-tubercular mycobacteria by nested multiplex PCR targeting IS6110, MTP40 and $32 \mathrm{kD}$ alpha antigen encoding gene fragments. BMC Infect Dis. 2016;16:123.

55. Yang YY, Fung CP, Yu IT, Chiang JH. Genital tuberculosis with peritonitis mimicking Meigs' syndrome: a case report. J Microbiol Immunol Infect. 1999;32:217-21.

56. Pesut D, Stojsić J. Female genital tuberculosis--a disease seen again in Europe. Vojnosanit Preg/. 2007;64:855-8.

57. Yassaee F, Farzaneh F. Familial tuberculosis mimicking advanced ovarian cancer. Infect Dis Obstet Gynecol. 2009;2009:736018.

58. Denue BA, Kwayabura SA, Ngadda HA. Ovarian tuberculosis masquerading as ovarian cancer in HIV infected patient: a plea to avoid unnecessary surgery. Pan Afr Med J. 2014;19:210.

59. Avan BI, Fatmi Z, Rashid S. Comparison of clinical and laparascopic features of infertile women suffering from genital tuberculosis (TB) or pelvic inflammatory disease (PID) or endometriosis. J Pak Med Assoc. 2001;51:393-9.

60. Sharma JB, Goyal M, Kumar S, et al. Concomitant female genital tuberculosis and endometriosis. Indian I Tuberc. 2017:64:173-7.

61. Gurgan T, Urman B, Yarali H. Results of in vitro fertilization and embryo transfer in women with infertility due to genital tuberculosis. Fertil Steril. 1996;65:367-70

62. Baird DT, Collins J, Egozcue J, et al. ESHRE Capri Workshop Group Fertility and ageing. Hum Reprod Update. 2005;11:261-76.

63. Igarashi H, Takahashi T, Nagase S. Oocyte aging underlies female reproductive aging: biological mechanisms and therapeutic strategies. Reprod Med Biol. 2015;14:159-69.

64. Morin SJ, Patounakis G, Juneau CR, et al. Diminished ovarian reserve and poor response to stimulation in patients $<38$ years old: a quantitative but not qualitative reduction in performance. Hum Reprod. 2018;33:1489-98.

65. Broekmans FJ, Kwee J, Hendriks DJ, et al. Hum Reprod Update 2006;12:685-718

66. Maheshwari A, Fowler P, Bhattacharya S. Assessment of ovarian reserve--should we perform tests of ovarian reserve routinely? Hum Reprod. 2006;21:2729-35.

67. Jirge PR. Ovarian reserve tests. J Hum Reprod Sci. 2011;4:108-13.

68. ASRM Practice Committee. Testing and interpreting measures of ovarian reserve: a committee opinion. Fertil Steril. 2012;98:1407-15.

69. Hehenkamp W, Looman C, Themmen A, et al. Anti-mullerian hormone levels in the spontaneous menstrual cycle do not show substantial fluctuation. J Clin Endocrinol Metab. 2006;91:4057-63.

70. Nelson SM, Yates RW, Lyall $\mathrm{H}$, et al. Anti-Müllerian hormone-based approach to controlled ovarian stimulation for assisted conception. Hum Reprod. 2009;24:867-75.

71. Dewailly D, Andersen CY, Balen A, et al. The physiology and clinical utility of anti-Mullerian hormone in women. Hum Reprod Update. 2014;20:370.

72. Nelson SM, Fleming R, Gaudoin M, et al. Antimüllerian hormone levels and antral follicle count as prognostic indicators in a personalized prediction model of live birth. Fertil Steril. 2015a;104:325-32.

73. Nelson SM, Klein BM, Arce JC. Comparison of antimüllerian hormone levels and antral follicle count as predictor of ovarian response to controlled ovarian stimulation in good-prognosis patients at individual fertility clinics in two multicenter trials. Fertil Steril. 2015;103:923-30.e1.
74. Van Rooij IA, Tonkelaar I, Broekmans FJ, et al. anti-Mullerian hormone is a promising predictor for the occurrence of the menopausal transition. Menopause. 2004;11:601-6.

75. Van Rooij IA, Broekmans FJ, Scheffer GJ, et al. Serum anti-Müllerian hormone levels best reflect the reproductive decline with age in normal women with proven fertility: a longitudinal study. Fertil Steril. 2005:83:979-87.

76. Lie Fong S, Visser JA, Welt CK, et al. Serum anti-müllerian hormone levels in healthy females: a nomogram ranging from infancy to adulthood. J Clin Endocrinol Metab. 2012;97:4650-5

77. Nelson SM, lliodromiti S, Fleming R, et al. Reference range for the antimüllerian hormone Generation II assay: a population study of 10,984 women, with comparison to the established Diagnostics Systems Laboratory nomogram. Fertil Steril. 2014;101:523-9.

78. Haahr T, Esteves SC, Humaidan P. Individualized controlled ovarian stimulation in expected poor-responders: an update. Reprod Biol Endocrinol. 2018;16:20.

79. Frydman R, Eibschitz I, Belaisch-Allart JC, et al. In vitro fertilization in tuberculous infertility. I In Vitro Fert Embryo Transf. 1985;2:184-9

80. Day CL, Abrahams DA, Lerumo L, et al. Functional capacity of Mycobacterium tuberculosis specific T cell responses in humans is associated with mycobacterial load. I Immunol. 2011;187:2222-32

81. Magombedze G, Dowdy D, Mulder N. Latent tuberculosis: models, computational efforts and the pathogen's regulatory mechanisms during dormancy. Front Bioeng Biotechnol. 2013;1:4.

82. D'Attilio L, Santucci N, Bongiovanni B, et al. Tuberculosis, the disrupted immune-endocrine response and the potential thymic repercussion as a contributing factor to disease physiopathology. Front Endocrinol (Lausanne). 2018:9:214.

83. Hamy AS, Porcher R, Cuvier $C$, et al. Ovarian reserve in breast cancer: assessment with anti-Müllerian hormone. Reprod Biomed Online. 2014;29:573-80.

84. Jindal UN, Verma S, Bala Y. Favorable infertility outcomes following antitubercular treatment prescribed on the sole basis of a positive polymerase chain reaction test for endometrial tuberculosis. Hum Reprod. 2012;27:1368-74.

85. Sunkara SK, Rittenberg $V$, Raine-Fenning $N$, et al. Association between the number of eggs and live birth in IVF treatment: an analysis of 400135 treatment cycles. Hum Reprod. 2011;26:1768-74

86. Devine K, Mumford SL, Wu M, et al. Diminished ovarian reserve in the United States assisted reproductive technology population: diagnostic trends among 181,536 cycles from the society for assisted reproductive technology clinic outcomes reporting system. Fertil Steril. 2015:104:612-9.

87. Lawson R, El-Toukhy T, Kassab A, et al. Poor response to ovulation induction is a stronger predictor of early menopause than elevated basal FSH: a life table analysis. Hum Reprod. 2003; 18:527-33

88. Anderson RA, Nelson SM, Wallace WH. Measuring anti-Müllerian hormone for the assessment of ovarian reserve: when and for whom is it indicated? Maturitas. 2012:7'28-33. 